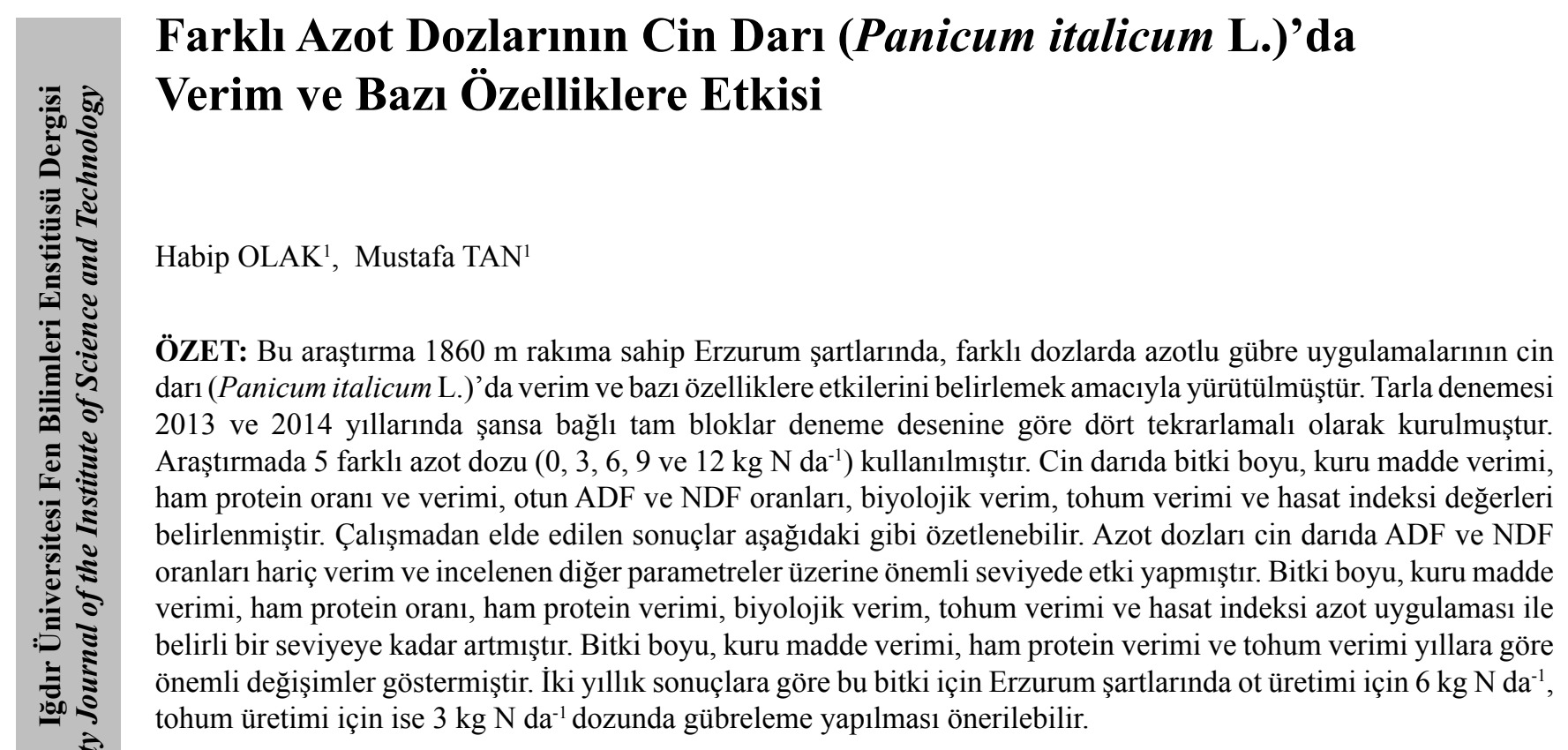

Anahtar Kelimeler: Cin darı, kuru madde verimi, tohum verimi, azotlu gübreleme

\title{
The Effects of Different Nitrogen Doses on Yield and Some Traits of Foxtail Millet (Panicum italicum L.)
}

\begin{abstract}
This research was conducted to determine the effects of different nitrogen doses on yield and some traits of foxtail millet (Panicum italicum L.) in altitude of $1860 \mathrm{~m}$ Erzurum conditions. The experiment was established in a randomized complete blocks design with four replications in 2013 and 2014. Five nitrogen doses $\left(0,3,6,9\right.$ and $\left.12 \mathrm{~kg} \mathrm{~N} \mathrm{da}^{-1}\right)$ were used in this study. Plant height, dry matter yield, crude protein content and yield, ADF and NDF content, biological yield, seed yield and harvest index were evaluated. Results of the study are summarized as follows. Nitrogen doses had a significant effect on the yields and measured other traits except for ADF and NDF ratios. They increased the plant height, dry matter yield, crude protein content and yield, biological yield, seed yield and harvest index up to certain level. Plant height, dry matter yield, crude protein yield and seed yield showed significant changes compared to the year. According to the mean of two years data, foxtail millet should be fertilized with $6 \mathrm{~kg} \mathrm{~N} \mathrm{da}^{-1}$ for hay production and $3 \mathrm{~kg} \mathrm{~N} \mathrm{da}^{-1}$ for seed production in Erzurum conditions.
\end{abstract}

Keywords: Foxtail millet, dry matter yield, seed yield, nitrogen fertilization

Atatürk Üniversitesi, Ziraat Fakültesi, Tarla Bitkileri Bölümü, Erzurum, Türkiye

Sorumlu yazar/Corresponding Author: Mustafa TAN, mustan@atauni.edu.tr 


\section{GIIRIŞ}

Yüksek rakımlı bölgelerde bitkisel üretimi sınırlayan en önemli faktörler vejetasyon periyodunun kısa olması ve yaz aylarının serin geçmesidir. Bu ekolojilerde yetiştiriciliği yapılan türlerin çeşitlendirilmesi hedeflendiğinde, daha çok serin mevsim bitkileri göz önüne alınmaktadır. Kaba yem üretimi için kullanılan tek yıllık türler arasında ilk akla gelenler baklagillerden fiğler (Vicia sp), buğdaygillerden ise serin mevsim tahılları ve çimler (Lolium sp.)'dir (Tan ve Serin, 2013; Serin ve Tan, 2014). Ancak kısa gelişme süresine ve hızlı büyüme oranına sahip bazı 1lıman mevsim türleri yüksek rakımlarda başarılı sonuçlar verebilirler. Örneğin mısır (Zea mays L.) subtropik iklim bitkisi olmasına rağmen, toleransı geniş bir türdür ve Erzurum'da silajlık olarak yetiştiriciliği mümkündür (Güney ve ark., 2010).

Bazen tarım arazilerinde çeşitli sebeplerden dolayı ekimlerin yapılması gecikmekte veya ekilen ürünün iptal edilip tarlaya yeni ürün ekilmesi gerekmektedir. Sıcak yaz aylarının başlangıcına rastlayan bu dönemden sonra serin mevsim bitkileri yeterince verim verememektedir (Temel ve Tan, 2002). Bu dönemde yetiştirilecek kısa vejetasyon süresine sahip bitki türlerine ihtiyaç vardır. Bu kapsamda düşünüldüğünde hızlı gelişme özelliğine sahip darlar (Panicum sp.) ilk akla gelen bitkilerdir. Dünyada yaygın olarak kültürü yapılan darı türlerinden birisi cin darı veya İtalyan darısı olarak isimlendirilen Panicum italicum L. (Syn. Seteria italica (L.) P. Beauv.)'dur. Tek yıllık olan cin darı bir sıcak mevsim bitkisidir. Anavatanı Uzakdoğu, Hindistan ve Orta Asya olarak kabul edilmektedir. Taneleri eski çağlardan beri ekmek ve lapa olarak insan beslenmesinde kullanılmıştır. Bugün tüm dünyanın subtropik ve 1lıman bölgelerinde çok yaygın olarak yetiştirilen bir kültür bitkisidir. 60-70 günde olgunlaşabildiği için, yazları kısa olan yerlerde bu bitkinin yetiştirilmesi mümkündür. Ot üretiminde ve geçici rotasyon meralarının tesisinde kullanıldığı gibi, tane yem elde etmek için de yetiştirilmektedir (Serin ve Tan, 2014). Ülkemizde bu bitkinin de içine girdiği dar1lar (P. italicum ve P. miliaceum L.) 2.691 ha ekim alanına sahiptir (Anonim, 2015).

Darılar ülkemizin batı bölgelerinde buğday hasadından sonra ikinci ürün olarak yetiştirilmektedir. Yaz aylarında tahıl hasadından sonra tarlalara ikinci ürün olarak ekilerek kullanılırlar. Kısa gelişme süresine sahip oldukları için bazı yörelerimizde "kırk günlük darı" olarak adlandırılırlar. Sıcak yaz aylarında hızlı bir gelişme ile kısa zamanda kaliteli kaba yem üretirler. Ancak yaz aylarında yapılan bu yetiştiricilikte sulama yapılırsa ve azotla gübrelenirse verim daha da artmaktadır (Aghtape et al., 2012; Serin ve Tan, 2014).

Buğdaygil yem bitkilerinden verimli ve kaliteli üretim yapabilmesi için azotlu gübreleme şarttır. Çünkü genellikle tarım arazilerimizde organik madde ve yarayışlı azot eksikliği görülmektedir. Bu nedenle bitkilerden yüksek verim alınması için toprağın besin maddesi dengesi muhafaza edilmelidir. Bu çerçevede düşünüldüğünde fakir topraklarda darı yetiştiriciliğinde azotlu gübre uygulamasına ihtiyaç vardır. Ancak uygulanacak gübre dozunun miktarı büyük önem taşır. Buğdaygillerin artan azot dozlarına karşı tepkisi, başlangıçtan en yüksek verime kadar azalan oranlarda artış ve en yüksek verime ulaştıktan sonra azalma şeklinde gerçekleşmektedir. Tepkinin azaldığı bu nokta en uygun azot dozu olarak kabul edilmektedir (Holmes, 1989). Buğdaygillerin azota karşı verdikleri bu tepki türlere göre değişmekle birlikte iklime bağlı olarak da yöreden yöreye farkl1lık göstermektedir. Dünyanın farklı yerlerinde yapılan gübreleme çalışmalarında darılarda ot ve tohum verimleri için $4.5-22.5 \mathrm{~kg} \mathrm{~N} \mathrm{da}^{-1}$ azot dozları önerilmiştir (Hassan et al., 2000; Kalaghatagi et al., 2000; Turgut ve ark., 2003; Turgut et al., 2006). Bu araştırma Türkiye'nin yüksek rakımlı bölgesi olan Doğu Anadolu Bölgesinde ilk defa denenecek olan cin darıda farklı azotlu gübre dozlarının ot ve tohum verimine ilişkin bazı özelliklere etkilerini belirlemek amacıyla yürütülmüştür.

\section{MATERYAL VE YÖNTEM}

Araştırma, 2013 ve 2014 yıllarında Erzurum'da, Atatürk Üniversitesi Ziraat Fakültesi sulu deneme alanında yürütülmüştür. Araştırmada cin darı (Panicum italicum L.)'nın yerel çeşidi 5 farklı azotlu gübre dozu $\left(0,3,6,9\right.$ ve $\left.12 \mathrm{~kg} \mathrm{~N} \mathrm{da}^{-1}\right)$ ile gübrelenmiştir. Azotlu gübre amonyum sülfat formunda uygulanmıştır. Deneme şansa bağlı tam bloklar deneme deseninde 4 tekrarlamalı olarak kurulmuştur. Tarla denemeleri her iki yılda da Mayıs ayı içerisinde kurulmuş, ot hasatları Temmuz ayında, tohum hasatları ise Ağustos ayında yapılmıştır. 
Ekimler sıra aralığı $20 \mathrm{~cm}$, parsel uzunluğu $3 \mathrm{~m}$ ve parsel genişliği $1.6 \mathrm{~m}$ (8 sıra) olacak şekilde yapılmıştır. Önceden hazırlanmış tohum yatağına $3 \mathrm{~kg} \mathrm{da}^{-1}$ tohum 2-3 cm toprak derinliğine el mibzeri ile ekilmiştir (Kün, 1985; Serin ve Tan, 2014). Yağış ve bitkilerin ihtiyacına göre salma şeklinde sulama yapılmıştır. Parsellerin yarısı ot, diğer yarısı tohum verimlerinin belirlenmesinde kullanılmıştır. Bitkiler \%50 çiçeklenme dönemine ulaştı̆̆ zaman ot için, tohumların renklendiği ve gerçek sertliğini kazandığı tam olgunlaşma döneminde ise tohum için hasat edilmiştir.

Araştırmada kuru madde, tohum, biyolojik ve ham protein verimleri, otun ham protein (HP), ADF (asit çözücülerde çözünmeyen lif) ve NDF (doğal çözücülerde çözünmeyen lif) oranları ile bitki boyu ve hasat indeksi incelenmiştir. Bitki boyu ölçümleri ot hasadı öncesinde her parselin orta kısmından rastgele seçilen 10 bitkide yapılmıştır. Kuru madde verimleri parsellerden biçilen otun önce açık havada, daha sonra $65^{\circ} \mathrm{C}$ 'ye ayarlı kurutma firınında 48 saat kurutulması ile belirlenmiştir. Ham protein oranları Kjeldahl yöntemiyle (Kacar, 1972), ADF ve NDF oranları ise ANKOM Fiber Analiz cihazında Van Soest (1963)'in belirttiği esaslara göre yapılmıştır. Tohum için hasat edilen bitkiler önce açık havada ve daha sonra kurutma firınında $40^{\circ} \mathrm{C}$ 'de kurutulup tartılmış önce biyolojik verimler, harmanlamadan sonra ise tohum verimleri ve hasat indeksi hesaplanmıştır.
Elde edilen veriler şansa bağlı tam bloklar deneme desenine göre MSTAT-C paket programı ile varyans analizine tabi tutulmuş ve önemli bulunan ortalamalar arasındaki farkl11ıklar LSD testi ile ortaya konulmuştur (Yıldız ve Bircan, 1991).

Deneme sahasından $0-30 \mathrm{~cm}$ derinlikten alınan topraklarının tekstür sınıfı killi-tındır. Deneme sahası topraklarında toplam tuz $\% 0.06, \mathrm{pH} 7,45$, kireç \%1.3, bitkilere yarayışl1 $\mathrm{P}_{2} \mathrm{O}_{5} 5.4 \mathrm{~kg} \mathrm{da}^{-1}, \mathrm{~K}_{2} \mathrm{O} 174 \mathrm{~kg} \mathrm{da}^{-1}$ ve organik madde \%0.97'dir (Çizelge 1). Bu değerlere göre deneme sahası toprakları tuzsuz, hafif alkali, az kireçli, bitkilere yarayışlı fosforca fakir, potasyumca zengin ve organik madde bakımından çok fakir durumdadır (Anonim, 1991).

Erzurum ilinin 2013 ve 2014 yıllarındaki 4 aylık deneme süresince (Mayıs-Ağustos) düşen toplam yağış miktarları çok büyük farklılıklar göstermiştir. 2013 y1lı kurak bir y1l olarak kayıtlara geçmiş, deneme süresince düşen toplam yağış miktarı $65.7 \mathrm{~mm}$ olmuştur. Normal bir y1l olan 2014 y1lında ise deneme süresince 141.6 mm yağış gerçekleşmiştir. Her ne kadar çalışma sulu şartlarda yürütülmüş olsa da bu durum deneme yıllarının birbirinden farklı olması sonucunu doğurmuştur. Aylık sıcaklık ortalaması her iki yılda da uzun yıllar ortalamasından (1960-2013) daha yüksek ve birbirine yakın ölçülmüştür (sırasıyla 16.4 ve $17.2{ }^{\circ} \mathrm{C}$ ). Yilların aylık nispi nem ortalamaları da birbirine yakın olmuş, 2013 ve 2014 yıllarında sırasıyla $\% 54.2$ ve $\% 52.5$ olarak belirlenmiştir.

Çizelge 1. Deneme yeri topraklarının bazı fiziksel ve kimyasal özellikleri

\begin{tabular}{|c|c|}
\hline Toprak Özellikleri & Sonuçlar \\
\hline Tekstür sınıfı & Killi-tın \\
\hline Tuzluluk & $\% 0.06$ \\
\hline $\mathrm{pH}$ & 7.45 \\
\hline Kireç $\left(\mathrm{CaCO}_{3}\right)$ & $\% 1.3$ \\
\hline Organik madde & $\% 0.97$ \\
\hline Bitkilere yarayışlı fosfor $\left(\mathrm{P}_{2} \mathrm{O}_{5}\right)$ & $5.4 \mathrm{~kg} \mathrm{da}^{-1}$ \\
\hline Bitkilere yarayışlı potasyum $\left(\mathrm{K}_{2} \mathrm{O}\right)$ & $174 \mathrm{~kg} \mathrm{da}^{-1}$ \\
\hline
\end{tabular}




\section{BULGULAR VE TARTIŞMA}

Araştırmada uygulanan azot dozlarının bitki boyu üzerine etkisi 0.05 ihtimal sinırlarında önemli bulunmuştur (Çizelge 2). İki yıllık ortalamaya göre en düşük bitki boyu $(61.2 \mathrm{~cm})$ azotlu gübre uygulanmayan kontrol parsellerinde belirlenirken, 3 ve $6 \mathrm{~kg} \mathrm{~kg} \mathrm{~N} \mathrm{da}^{-1}$ dozlarında önemli artışlar görülmüştür. Ancak azotun daha yüksek dozları bitki boyunu istatistiksel olarak değiştirmemiştir. Araştırmanın ikinci yılında bitki boyu ilk y1la göre belirgin olarak daha yüksek olmuş, bu farkl1l1k istatistiksel olarak 0.01 seviyesine önemli bulunmuştur (Çizelge 2).

Çizelge 2. Farklı dozlarda azotla gübrelenen cin darının bitki boyu, kuru madde ve ham protein verimi

\begin{tabular}{cccccccccc}
\hline $\begin{array}{c}\text { Azot } \\
\left(\mathrm{kg} \mathrm{N} \mathrm{da}^{-1}\right)\end{array}$ & \multicolumn{3}{c}{$\begin{array}{c}\text { Bitki Boyu } \\
(\mathrm{cm})\end{array}$} & & \multicolumn{3}{c}{$\begin{array}{c}\text { Kuru Madde Verimi } \\
\left(\mathrm{kg} \mathrm{da}^{-1}\right)\end{array}$} & \multicolumn{3}{c}{$\begin{array}{c}\text { Ham Protein Verimi } \\
\left(\mathrm{kg} \mathrm{da}^{-1}\right)\end{array}$} \\
\hline & 2013 & 2014 & Ort. & 2013 & 2014 & Ort. & 2013 & 2014 & Ort. \\
\hline 0 & 47.1 & 75.3 & $61.2 \mathrm{c}$ & 246.9 & 564.4 & $405.7 \mathrm{~B}$ & 28.4 & 71.1 & $49.8 \mathrm{~B}$ \\
3 & 52.5 & 77.5 & $65.0 \mathrm{bc}$ & 285.7 & 602.7 & $444.2 \mathrm{~B}$ & 34.9 & 74.9 & $54.9 \mathrm{AB}$ \\
6 & 66.6 & 83.8 & $75.1 \mathrm{a}$ & 343.0 & 698.6 & $520.8 \mathrm{AB}$ & 41.5 & 84.0 & $62.7 \mathrm{AB}$ \\
9 & 62.1 & 79.2 & $70.7 \mathrm{ab}$ & 360.6 & 669.1 & $514.8 \mathrm{AB}$ & 50.2 & 94.2 & $72.2 \mathrm{~A}$ \\
12 & 65.0 & 80.3 & $72.7 \mathrm{ab}$ & 488.3 & 664.2 & $576.3 \mathrm{~A}$ & 58.1 & 82.2 & $70.1 \mathrm{~A}$ \\
Ortalama & $58.6 \mathrm{~B}$ & $79.2 \mathrm{~A}$ & 68.9 & $344.9 \mathrm{~B}$ & $639.8 \mathrm{~A}$ & 492.4 & $42.6 \mathrm{~B}$ & $81.3 \mathrm{~A}$ & 61.9 \\
\hline Azot x Y11 & & ö.d. & & & o.d. & & & ö.d. & \\
\hline
\end{tabular}

ö.d.: önemsiz, küçük harfler 0.05 , büyük harfler ise 0.01 seviyesinde önemlilik gösterir

Azotlu gübre dozları kuru madde ve ham protein verimini de çok önemli seviyede etkilemiştir. Hem kuru madde verimi hem de ham protein verimi en düşük kontrol parsellerinde belirlenmiştir. İki y1llık ortalamaya göre kuru madde verimi azotun en yüksek dozuna kadar artış göstermiş, fakat bu artış $6 \mathrm{~kg} \mathrm{~N} \mathrm{da}^{-1}$ dozundan sonra önemsiz olmuştur. Ham protein veriminde ise en yüksek değerler $9 \mathrm{~kg} \mathrm{~N} \mathrm{da}^{-1}$ ve $12 \mathrm{~kg} \mathrm{~N} \mathrm{da}^{-1}$ dozunda kaydedilmiş ve bu değerler istatistiki olarak aynı gurupta yer almışlardır. Azotun $3 \mathrm{~kg} \mathrm{~N} \mathrm{da}^{-1}$ dozundan sonraki ham protein verimi değişimleri istatistiksel olarak önemsiz bulunmuştur. Y1llara göre ise kuru madde ve ham protein verimleri 0.01 ihtimal seviyesinde önemli değişim göstermiş ve her iki parametrede de en yüksek değerler ikinci yılda belirlenmiştir (Çizelge 2).

Cin darının ham protein, ADF ve NDF oranları yıllara göre değişim göstermemiştir (Çizelge 3). Azotlu gübre dozları ise ham protein oranını 0.01 ihtimal sınırlarında çok önemli seviyede etkilerken, ADF ve NDF oranları üzerinde istatistiksel olarak etkisiz olmuştur. 
Çizelge 3. Farklı dozlarda azotla gübrelenen cin darının ham protein, ADF ve NDF oranları

\begin{tabular}{|c|c|c|c|c|c|c|c|c|c|}
\hline \multirow{2}{*}{$\begin{array}{c}\text { Azot } \\
\left(\mathrm{kg} \mathrm{N} \mathrm{da}^{-1}\right)\end{array}$} & \multicolumn{3}{|c|}{$\begin{array}{c}\text { Ham Protein Oran } 1 \\
(\%)\end{array}$} & \multicolumn{3}{|c|}{$\begin{array}{l}\text { ADF Oran } 1 \\
(\%)\end{array}$} & \multicolumn{3}{|c|}{$\begin{array}{l}\text { NDF Oran1 } \\
(\%)\end{array}$} \\
\hline & 2013 & 2014 & Ort. & 2013 & 2014 & Ort. & 2013 & 2014 & Ort. \\
\hline 0 & 12.57 & 12.56 & $12.56 \mathrm{~B}$ & 38.80 & 38.37 & 38.59 & 59.95 & 64.71 & 62.32 \\
\hline 3 & 12.21 & 12.44 & $12.33 \mathrm{~B}$ & 38.20 & 36.77 & 37.49 & 59.50 & 64.66 & 62.08 \\
\hline 6 & 12.20 & 11.97 & $12.09 \mathrm{~B}$ & 35.60 & 39.33 & 37.47 & 59.90 & 60.23 & 60.06 \\
\hline 9 & 13.93 & 14.04 & $13.98 \mathrm{~A}$ & 38.20 & 36.52 & 37.36 & 56.13 & 65.49 & 60.81 \\
\hline 12 & 11.89 & 12.37 & $12.13 \mathrm{~B}$ & 36.10 & 34.95 & 35.53 & 63.18 & 62.69 & 62.93 \\
\hline Ortalama & 12.56 & 12.67 & 12.62 & 37.38 & 37.19 & 37.29 & 59.73 & 63.55 & 61.64 \\
\hline Azot x Y1l & \multicolumn{3}{|c|}{ ö.d. } & \multicolumn{3}{|c|}{ ö.d. } & \multicolumn{3}{|c|}{ ö.d. } \\
\hline
\end{tabular}

ö.d.: önemsiz, büyük harfler 0.01 seviyesinde önemlilik gösterir

İki yıllık ortalama sonuçlara göre en yüksek ham protein oranı (\%13.98) $9 \mathrm{~kg} \mathrm{~N} \mathrm{da}^{-1}$ uygulamasında belirlenmiştir. Diğer dozların ham protein oranları istatistiksel olarak daha düşük bulunmuştur. Araştırmada cindarının ortalama ham protein, ADF ve NDF oranları sirasiyla \%12.62, 37.29 ve 61.64 olarak belirlenmiştir.

Azotlu gübre uygulaması cin darının biyolojik verimi üzerine 0.05 ihtimal sınırlarında önemli etki yapmıştır. En düşük biyolojik verim $\left(726.5 \mathrm{~kg} \mathrm{da}^{-1}\right)$ kontrol parsellerinde belirlenirken, azot uygulaması ile önemli seviyede artış olmuş, fakat azot dozlarının etkileri istatistiksel olarak aynı seviyede bulunmuşlardır. Cin darıda biyolojik verim birinci y1l ortalama $800.9 \mathrm{~kg} \mathrm{da}^{-1}$, ikinci y1l ise $791.9 \mathrm{~kg}$ $\mathrm{da}^{-1}$ olarak ölçülmüştür. Yılların biyolojik verim üzerinde önemli bir etkisi olmamış, fakat azot $\mathrm{x}$ y1l interaksiyonu istatistiksel olarak çok önemli bulunmuştur. $\mathrm{Bu}$ durum azot dozlarının yıllara göre farklı etki yapmalarından kaynaklanmıştır. Örneğin ilk y1l azot dozlarına bağlı olarak verim sürekli artarken ikinci yılda $3 \mathrm{~kg} \mathrm{~N} \mathrm{da}^{-1}$ dozuna kadar artmış daha sonra azalma eğilimine girmiştir (Çizelge 4). Çizelgeden anlaşılacağı üzere ilk y1l genellikle yüksek azot dozları, ikinci yıl ise düşük azot dozları daha fazla biyolojik verim üretmişlerdir.

İki yıllık ortalama sonuçlara göre en düşük tohum verimi (139.5 $\left.\mathrm{kg} \mathrm{da}^{-1}\right)$ kontrol parsellerinde, en yüksek ise (198.9 $\left.\mathrm{kg} \mathrm{da}^{-1}\right) 9 \mathrm{~kg} \mathrm{~N} \mathrm{da}^{-1}$ dozunda belirlenmiştir. Azotun etkisi istatistiksel olarak önemli bulunmuş, fakat $3 \mathrm{~kg} \mathrm{~N} /$ da'dan $12 \mathrm{~kg} \mathrm{~N} /$ da dozuna kadar olan verimler istatistiksel olarak aynı guruba girmişlerdir. Araştırmanın ilk yılında $203.8 \mathrm{~kg} \mathrm{da}^{-1}$ olan ortalama tohum verimi ikinci yılda önemli bir düşüş göstererek $148.2 \mathrm{~kg} \mathrm{da}^{-1}$ bulunmuştur. Azotlu gübre dozlarının tohum verimi üzerine olan etkileri yıllara göre farkl11ık gösterdiği için azot x yıl interaksiyonu da istatistiksel olarak önemli bulunmuştur. Her iki yıldaki uygulamalar arasında en yüksek tohum verimi $\left(256.8 \mathrm{~kg} \mathrm{da}^{-1}\right)$ birinci y1l $9 \mathrm{~kg} \mathrm{~N} \mathrm{da}^{-1}$ dozunda tespit edilmiştir. Bunu takip eden diğer yüksek verimler ilk yılda ve yüksek azot uygulamalarında ortaya çıkmıştır (Çizelge 4). 
Çizelge 4. Farklı dozlarda azotla gübrelenen cin darının biyolojik verim, tohum verimi ve hasat indeksi değerleri

\begin{tabular}{|c|c|c|c|c|c|c|c|c|c|}
\hline \multirow{2}{*}{$\begin{array}{c}\text { Azot } \\
\left(\mathrm{kg} \mathrm{N} \mathrm{da}^{-1}\right)\end{array}$} & \multicolumn{3}{|c|}{$\begin{array}{l}\text { Biyolojik Verim } \\
\qquad\left(\mathrm{kg} \mathrm{da}^{-1}\right)\end{array}$} & \multicolumn{3}{|c|}{$\begin{array}{l}\text { Tohum Verimi } \\
\qquad\left(\mathrm{kg} \mathrm{da}^{-1}\right)\end{array}$} & \multicolumn{3}{|c|}{$\begin{array}{l}\text { Hasat İndeksi } \\
(\%)\end{array}$} \\
\hline & 2013 & 2014 & Ort. & 2013 & 2014 & Ort. & 2013 & 2014 & Ort. \\
\hline 0 & 628.4 & 824.7 & $726.5 \mathrm{~b}$ & 117.8 & 161.2 & $139.5 \mathrm{~b}$ & 18.8 & 19.6 & $19.2 \mathrm{~b}$ \\
\hline 3 & 729.4 & 908.3 & $818.9 \mathrm{ab}$ & 177.4 & 180.5 & $178.9 \mathrm{ab}$ & 24.3 & 19.9 & $22.1 \mathrm{ab}$ \\
\hline 6 & 776.2 & 760.6 & $768.4 \mathrm{ab}$ & 226.4 & 140.9 & $183.7 \mathrm{ab}$ & 29.2 & 18.5 & $23.9 \mathrm{a}$ \\
\hline 9 & 898.7 & 808.6 & $853.6 \mathrm{a}$ & 256.8 & 140.4 & $198.9 \mathrm{a}$ & 28.6 & 15.6 & $22.1 \mathrm{ab}$ \\
\hline 12 & 972.1 & 657.5 & $814.8 \mathrm{ab}$ & 240.6 & 117.9 & $179.3 \mathrm{ab}$ & 24.8 & 17.9 & $21.4 \mathrm{ab}$ \\
\hline Ortalama & 800.9 & 791.9 & 796.4 & $203.8 \mathrm{~A}$ & $148.2 \mathrm{~B}$ & 176.0 & 25.1 & 18.3 & 21.7 \\
\hline Azot x Yil & \multicolumn{3}{|c|}{ ** (LSD: 202.2) } & \multicolumn{3}{|c|}{ ** (LSD: 91.8) } & \multicolumn{3}{|c|}{ ö.d. } \\
\hline
\end{tabular}

ö.d.: önemsiz, küçük harfler 0.05 , büyük harfler ise 0.01 seviyesinde önemlilik gösterir

Hasat indeksi üzerinde yıllar ve azot $\mathrm{x}$ y1l interaksiyonu önemsiz, azot uygulaması önemli olmuştur. Tohum verimi ve biyolojik verimde olduğu gibi en düşük hasat indeksi (\%19.2) azot uygulanmadan yetiştirilen parsellerden alınırken, azot uygulaması ile artış göstermiştir. Bu artış $6 \mathrm{~kg}$ $\mathrm{N} \mathrm{da}^{-1}$ dozunda en yüksek seviyeye gelmiş (\%23.9), daha yüksek azot dozlarında bir miktar düşmüştür. Ancak azotun 3, 6, 9 ve $12 \mathrm{~kg} \mathrm{~N} \mathrm{da}^{-1}$ dozlarının hasat indeksi değerleri istatistiksel olarak benzerdir (Çizelge 4).

Cin darı yazlık olarak yetiştiriciliğe uygun tek y1ll1k bir sicak mevsim bitkisidir. Sicak yaz aylarında hızlı büyüme oranı ile kısa zamanda ürün verebilmektedir. Bu çalışma bitkinin Erzurum şartlarında da başarı ile yetiştirilebileceğini ortaya koymuştur. Ancak yıllık iklim şartları bitkinin verimine büyük etki yapmaktadır. Araştırmada bitki boyu, kuru madde verimi, ham protein verimi ve tohum verimi yıllara göre büyük değişim göstermiştir. Bitki boyu, kuru madde verimi ve ham protein verimi ikinci yıl daha yüksek olurken, tohum verimi ilk yıl daha fazla olmuştur. Araştırma sulu şartlarda yürütülmüştür, ancak yıllar arasında yağış miktarının büyük farklılık göstermesi bitki gelişmesine önemli etkiler yapmıştır. 2013 yılı deneme süresince (Mayıs-A ğustos) oldukça kurak geçmiştir (toplam $65.7 \mathrm{~mm}$ ). 2014 y1lında ise deneme aylarında toplam $141.6 \mathrm{~mm}$ yağış düşmüştür. $\mathrm{Bu}$ durum ilk yılda bitkilerin generatif gelişmeye daha çabuk geçmesine ve tohum veriminin artmasına neden olmuştur. İkinci yılda ise vejetatif gelişme periyodu daha uzun olmuş, bitkiler daha fazla boylanmış ve ot verimleri daha yüksek bulunmuştur. Kanada'da kum darı, cin darı, yulaf ve arpa ile çalışan May et al. (2007), yağışlı yıllarda darıların ot veriminin daha yüksek olduğunu bildirmişlerdir.

Organik maddenin fakir olduğu topraklarda azotlu gübre uygulaması bitkilerde büyüme ve gelişmeyi artırmaktadır. Bu çalışmada da azotlu gübre uygulaması cin darıda bitki boyu, kuru madde verimi, ham protein verimi, ham protein oran1, tohum verimi, biyolojik verim ve hasat indeksini önemli seviyede etkilemiştir. Fakat bu parametrelerdeki en yüksek değeri ortaya çıkaran azot dozlarında değişiklikler görülmüştür. Bitki boyu ve hasat indeksi $6 \mathrm{~kg} \mathrm{da}^{-1}$, kuru madde verimi $12 \mathrm{~kg} \mathrm{da}^{-1}$, biyolojik verim, tohum verimi, ham protein oran1 ve ham protein verimi $9 \mathrm{~kg} \mathrm{da}^{-1}$ azot dozlarında en yüksek seviyeye ulaşmışlardır. Fakat 
kuru madde veriminin $6 \mathrm{~kg} \mathrm{da}^{-1}$, tohum veriminin ise $3 \mathrm{~kg} \mathrm{da}^{-1}$ 'dan daha yüksek azot dozlarındaki artışları istatistiksel olarak önemli değildir. Her ne kadar cin darının büyüme ve gelişmesi gübre azotuna bağlı olsa da bitkinin kısa sürede gelişmesi ve olgunlaşması çok yüksek dozlarda azot kullanımını engellemiştir. $\mathrm{Bu}$ çalışmada yüksek verimleri sağlayan azot dozlarının başka çalışmalardan daha düşük olması Erzurum'da bitki gelișme süresinin kısa olmasından kaynaklanmış olabilir. Örneğin, Turgut ve ark. (2003) Bursa sulu şartlarında biyolojik verimde en yüksek değeri $1275 \mathrm{~kg} / \mathrm{da}$ olarak $15 \mathrm{~kg}$ $\mathrm{N} \mathrm{da}^{-1}$ dozunda belirlemişlerdir. Çalışmamıza benzer olarak Hassan et al. (2000), değişik dozlarda azotlu gübre uygulanan cin darıda en yüksek bitki boyunu $4.5 \mathrm{~kg} \mathrm{~N} \mathrm{da}^{-1}$ uygulamasında belirlemiş, yüksek azot dozunda bitki boyu artışı olmamıştır. Turgut et al. (2006) da bu bitkide en yüksek bitki boyunu $6 \mathrm{~kg} \mathrm{~N} \mathrm{da}{ }^{-1}$ dozunda belirlenmişlerdir $(66.6 \mathrm{~cm})$. Kalaghatagi et al. (2000), en yüksek kuru ot verimini $4.5 \mathrm{~kg} \mathrm{~N} \mathrm{da}^{-1}$ gübre dozunda belirlemişlerdir. Tohum verimi üzerinde azotun etkilerini araştıran Hassan et al. (2000) 0, 1.5, 3.0, 4.5 ve $6.0 \mathrm{~kg} \mathrm{da}^{-1}$ azot dozlarında sirasıyla $120,149,160,182$ ve $187 \mathrm{~kg}$ $\mathrm{da}^{-1}$ tohum verimi belirlemişlerdir. $\mathrm{Bu}$ çalışmaya benzer olarak en yüksek dozdaki artışın önemsiz olduğunu bildirmişlerdir.

Panicum italicum bir sicak mevsim bitkisidir. Dolayısıyla bu tür bitkilerde yüksek fotosentetik kapasiteye bağlı olarak hızlı büyüme ve gelişme görülür. Ancak bu durum besin kompozisyonu ve yem değerinde de bazı olumsuzluklar ortaya çıkarır. $\mathrm{Bu}$ gruptaki sıcak mevsim bitkilerinde genellikle ham protein oranları düşük, ADF ve NDF gibi yapısal maddeler yüksektir. Nitekim çalı̧̧mamızda da bu durum belirgin olarak görülmektedir. Bu bitki ile çalışan Taira (1968) ve Mohajer et al. (2011), ham protein oranında; Zhang et al. (2010) ise ADF ve NDF oranlarında bu çalışmadaki değerlere benzer sonuçlar bulmuşlardır.

\section{SONUC}

$\mathrm{Bu}$ araştırma sonuçları kısa gelişme süresi olan cin darının Erzurum şartlarında yazlık olarak yetiştirilebileceğini ortaya koymuştur. Ancak bitkinin yeterli verim verebilmesi için azotla gübrelenmesi gerekir. Bu bitkiye ot üretimi için $6 \mathrm{~kg}$ $\mathrm{N} \mathrm{da}^{-1}$, tohum üretimi için ise $3 \mathrm{~kg} \mathrm{~N} \mathrm{da}^{-1}$ dozunda azotlu gübre uygulanması tavsiye edilebilir.

\section{TEŞEKKÜR}

Bu çalışma Atatürk Üniversitesi Bilimsel Araştırma Projeleri Fonundan desteklenmiştir (BAP-2013/384)

\section{KAYNAKLAR}

Aghtape AA, Ghanbari A, Sirousmehr A, Siahsar B, Asgharipour M, Tavssoli A, 2012. Effect of irrigation with wastewater and foliar fertilizer application on some forage characteristics of foxtailmillet (Setaria italica). International Journal of Plant Physiology and Biochem, 3(3): 34-42.

Anonim, 1991. Türkiye Toprakları Verimlilik Envanteri. T.C. Tarım Orman ve Köy İşleri Bakanlığı. Köy Hizmetleri Genel Müdürlüğü, Ankara.

Anonim, 2015. TÜİK, Türkiye İstatistik Kurumu Bitkisel Üretim Verileri, Ankara.

Güney E, Tan M, Dumlu Gül Z, Gül İ, 2010. Erzurum şartlarında bazı silajlık mısır çeşitlerinin verim ve silaj kalitelerinin belirlenmesi. Atatürk Üniv. Ziraat Fak. Derg., 41(2): 105 111.

Hassan SME, Rahman MS, Hossain MF, Amin MR, Alam MM, 2000. Evaluation of planting density and nitrogen on the performance of Kaon (Setaria italica (L). Beauv.). Pakistan Journal of Biological Sciences, 3(11): 1863-1864

Holmes W, 1989. Grass, Its Production and Utilization. The British Grassland Society by Black Well Scientific Puclications, Oxford, England, 306 p.

Kacar B, 1972. Toprağın Kimyasal Analizleri: II. Bitki Analizleri Ankara Üniv. Ziraat Fak. Yay. No: 453, Ankara, 464 s.

Kalaghatagi SB, Jirali DI, Wali SY, Nagod MS, 2000. Remove from marked records response of foxtail millet (Setaria italica) to nitrogen and phosphorus under rainfed conditions of northern dry zone of Karnataka. Annals of Arid Zone (India), 39(2): 169-171.

Kün E, 1985. Sıcak İklim Tahılları. Ankara Üniv. Ziraat Fak. Yay: 953, Ders Kitab1, Ankara, 275 s.

May WE, Klein LH, Lafond GP, Mc Connell JT, Phelps MS, 2007. The suitability of cool- and warm-season annual cerealspecies for winter grazing in Saskatchewan. Canadian Journal of Plant Science 87(4): 739-752.

Mohajer S, Dastenai MV, Taha RM, 2011. Forage quality of foxtail millet (Setaria italica) cultivars at different phenological stages in Karaj region, Iran. Journal of Food, Agriculture \& Environment, 9(2): 304-308 
Serin Y, Tan M, 2014. Buğdaygil Yembitkileri. Atatürk Üniv. Yay. No: 859, Ziraat Fak. Yay. No: 334, Ders Kit. No: 81, Erzurum, $263 \mathrm{~s}$.

Taira H, 1968. Amino Acid Composition of Different Varieties of Foxtail Millet (Setaria italica). J. Agr. Food. Chem., 16(6): 1025-1027.

Tan M, Serin Y, 2013. Baklagil Yembitkileri. Atatürk Üniversitesi Ziraat Fakültesi Ders Yay. No: 190, Erzurum, 222 s.

Temel S, Tan M, 2002. Erzurum şartlarında adi fiğ (Vicia sativa L.)'in ekim ve hasat zamanlarının belirlenmesi üzerine bir araştırma. Atatürk Üniv. Ziraat Fak. Der., 33 (4): 363-368.

Turgut I, Duman A, Wietgrefe GW, Acikgoz E, 2006. Effect of seeding rate and nitrogen fertilization on proso millet under dryland and irrigated conditions. Journal of Plant Nutrition, 29: 2119-2129.
Turgut İ, Duman A, Wietgrefe GW, Açıkgöz E, 2003. Sulu ve kuru koşullarında yetiştirilen kumdarı (Panicum miliaceum L.)'da ekim sıklığı ve azot dozlarının verim ve verim öğeleri üzerine etkisi. Türkiye 5. Tarla Bitkileri Kongresi, 13-17 Ekim 2003, Diyarbakır, Cilt: II, s: 293-297.

Van Soest PJ, 1963. The use of detergents in the analysis of fibrous feeds. II. A rapid method for determination of the fiber and lignin. JAOAC 46: 829-835.

Yıldız N, Bircan H, 1991. Uygulamalı İstatistik Atatürk Üniversitesi Yay. No: 704-308-60.

Zhang Q, Shen Y, Nan Z, Whish J, Bell L Bellotti W, 2010. Production and nutritive value of alternative annual forage crop options in a rainfed region of western China. Proceedings of 15th Agronomy Conference, 2010, 15-18 November, New Zealand. 